\title{
Unsettled intimacies: revisiting Edith Wharton's The Custom of the Country through Nella Larsen's Quicksand
}

Kedon Willis

Kedon Willis is a PhD candidate at the University of Florida. His research focuses on the intersection of queer identity and regional folklore by writers of different linguistic traditions in the Caribbean.

Email: kedonkwillis@ufl.edu

ORCID: https://orcid.org/0000-0002-0599-8389

DOI 10.17159/2309-9070/tvl.v.56i1.6273

\section{Unsettled intimacies: revisiting Edith Wharton's The Custom of the Country through Nella Larsen's Quicksand}

Scholars have highlighted Nella Larsen's textual interventions into aspects of Edith Wharton's major works. The interventions, they claim, not only unmask Wharton's pointed operations of erasure against people of color but, in some cases, showcase her racism. None of these works, however, devote critical analysis to the interventions staged in Wharton's The Custom of the Country (1913), the novel that, I argue, is her most definitive statement on the role of market-based capitalism on the fate of Western civilization. Larsen's Quicksand (1928) shares many of Custom's thematic concerns. Though writing from different class and racial perspectives, both writers must account for the social developments that spilled over from the previous century to articulate their implications for their heroines in terms of marriage, family, work, divorce, sex, and race relations on a trans-Atlantic scale. However, given that Custom almost entirely elides the presence of people of color, assessing it alongside Quicksand animates the specter of colonialism that haunts the text, inviting us to remember why not all bodies, as M. Jacqui Alexander argues in "Not Just (Any) Body Can Be a Citizen," can be imagined as naturalized citizen subjects within the rubric of modern capitalism. Keywords: Nella Larsen, Edith Wharton, colonialism, capitalism, motherhood, racism.

\section{Introduction}

Edith Wharton and Nella Larsen wrote during an era where both Europe and the United States grappled with the changing roles of women in society. As writers of the early twentieth-century, with significant ties to Europe that extended into their fiction, they were uniquely positioned to filter trans-Atlantic preoccupations around 'the modern woman.' In Europe, according to Gail Cunningham (1978), the "New Woman" emerged from the tumult of anti-establishment ideas during the fin-de-siècle period, allowing some women to feasibly envision a life outside of marriage. In the United States, technological advancements and increased job opportunities following the Civil War allowed a larger share of women to challenge the separate-spheres ideology and provided impetus for nineteenth-century feminist activism (Cott 125). It was this purported assault on marriage that posed questions for the naturalized order of the heteropatriarchal family (Cunningham 2).

Gothic literature at this time proved a fruitful arena for tackling this anxiety. 
For instance, Bram Stoker's Dracula (1897) features Lucy who, espousing feminist ideals, is turned into a vampire, becomes wildly erotic, and preys on children. Like other gothic works that engage with themes of female agency and monstrosity, Dracula embodies a cultural preoccupation with an idea of change that challenges the moral, economic, and reproductive purpose of the conjugal family. It is against this backdrop that I examine the works of Wharton and Larsen. While they cannot be classified as gothic writers, they have invested key heroines with signifiers of the gothic that would pose them as perverse and a threat to their societies. Unlike the 'untraditional' women of Stoker, Wharton's and Larsen's protagonists engage in a depth of interrogation that exposes the operations of the Euro-American nation state as antithetical to women's full agency as citizens and, in Larsen's case, as constructed on the abjection of blackness. Roughly a century prior, Mary Shelley had engaged in a similar interrogation of citizenship in Frankenstein. In it, the scientist Victor Frankenstein creates a human from various inanimate parts that has advanced intellect but is physically freakish. The creature, shunned by a society that could not reconcile his poetic mind with his monstrous appearance, is charged by a sense of vengeance against his creator for dooming him to such an existence. By repeatedly scrutinizing the ego-driven motives of the scientist, however, Shelley undercuts a simple understanding of who is the text's real monster. In Black Frankenstein, Elizabeth Young taps further into the novel's colonial resonance by connecting the creature as both product and belier of European enlightenment ideals to the abjection of black bodies as intrinsic to the ontology of the modern nation state. As such, I engage with this signifier of the gothic to show how Wharton and Larsen wrote back against the concept of the subversive female to expose the Euro-American model of the nation state as the site of monstrosity.

Wharton's The Custom of the Country (1913) and Larsen's Quicksand (1928) both depict willful and, at times, repellent heroines who spend significant time in both the US and Europe. The metaphoric operations of the Frankenstein story show how these women are constructed out of conflicting Euro-American ideals and are then charged by a confluence of catalytic events that crescendos into a rebellion. While this examination shifts critical attention towards the writers' maneuvers in unmasking apparatuses at work in dehumanizing the modern woman, the metaphor works on different registers along racial lines. Through Quicksand, the perversities of a market-obsessed society work to move Custom's Undine Spragg away from an ideal of citizenship with which her whiteness endows her. The biracial Helga Crane from Quicksand, however, is already prefigured as a non-localized Other, untethered from any stable notion of belonging, because of her brown skin and illegitimate birth. Though Custom almost entirely elides the presence of people color, assessing it alongside Quicksand animates the specter of colonialism that haunts the text.

In her essay on the cross-textual relationship between Wharton and Larsen, Emily 
Orlando juxtaposes a Harlem club scene from Twilight Sleep (1927) and places it in direct conversation with a vaudeville scene in Quicksand (1928). Whereas in Wharton's (Twilight Sleep 147) text, narrative interest in the black performers is limited to their function as consumable objects flung about like dark fruits that gave off "crimson bursts of laughter splitting open on white teeth," in Larsen's text the reader is repeatedly led back to ponder the spectacle of cavorting black bodies as a critique of the impossibility of apolitical black presence in a white-dominated culture. In offering this 'revision,' Larsen not only 'reauthorizes' the implications of black performance as spectacle "with the kind of authority that Wharton, as a white, Europeanized American, cannot access" (Orlando 38), but also unmasks the forms of silencing and elisions that writers like Wharton engaged in to create a white-centered ideology that was supposedly race-neutral.

Orlando's analysis stands alongside a number of other scholars who have begun decrypting the racial registers of Wharton's works. In one of the earlier essays on the topic, "Edith Wharton and the Issue of Race," Elizabeth Ammons argues that the near-complete erasure of people of color masks the racial ideology of a dominant white culture, or "erasure camouflaging insistent re-inscription" (Ammons 72). Ammons engages with a familiar catalogue of Wharton's works, namely The House of Mirth (1905), Summer (1917), and The Age of Innocence (1920). Similarly, Hildegard Hoeller's "Invisible Blackness" unpacks Wharton's short story “Old Maid" to unravel tropes of the tragic mulatto which are overlaid on the story's three ostensibly white characters. Although Linda Dittmar's "When Privilege Is No Protection" analyzes Larsen's Quicksand in relation to Wharton's The House of Mirth, and Nick Bromell's "Reading Democratically" scrutinizes The House of Mirth to show its literary traces in Larsen's Passing (1929), very few of these critical works engage with Wharton's Custom. I argue that this text represents the author's most definitive stance on the United States as a vanguard global power in contradistinction to the retreating position of Western Europe. A notable exception is Stuart Hutchinson's "Sex, Race and Class in Edith Wharton." However, this overview of Custom stops short of the broader global and capitalist implications of movements within the novel and focuses mainly on the superficiality of the protagonist. Orlando (34) admirably teases out both the overt and not-so-overt traces of Wharton's influence on Larsen's writing, going so far as to say it shows an engagement of revisionist dialogue that "spanned the length of [Larsen's] literary career." Of particular note is her sieving of Larsen's text, particularly in her unpublished "Sank," to show evidence of appropriation of Wharton's diction. Far from accusing her of plagiarism, Orlando shows the inventiveness of Larsen's engagement with Wharton as an ironic form of critique. With this in mind, it is curious that Orlando and other scholars overlook the relation between Custom and Quicksand. The protagonists in both novels are engaged to the consumerist principles of an early twentieth-century market age and are averse to 
the traditional confines of marriage. Importantly, both novels also set a significant part of their analysis against the backdrop of a European journey.

Larsen and Wharton engage in a critique of marriage as an institution of patriarchal power. Wharton's work especially unearths how trans-Atlantic capitalism colludes in solidifying an asymmetrical gender dynamic. As scholars such as Orlando have affirmed, Larsen overturns Wharton's reductive take on early twentieth-century women's concerns by illuminating the very different struggles of black women in their quest for agency and showing how those concerns refract significantly through the prism of class. However, noting Custom's critical plotting of marriage as indicative of the historical exchanges that bind the United States to metropoles in Europe (exchanges pertinent to the continued growth of a wealthy white elite), Wharton's curated erasure of race manifests a longing for heteronormative Anglo-Saxon values as the engineering force of this imagined community. Given the overlooked similarities existing between Custom and Quicksand, Larsen's focus on race in both the US and Europe serves as a crucial rebuttal of racial erasure in both the United States and Europe.

\section{Undine Spragg: the ideal monster}

Undine Spragg evidences Wharton's most withering critique on modern societies being governed by the precepts of market economies. In Undine's desire to scale the heights of the jet-set class in both Europe and North America, she forces her father to move the family to New York, ultimately precipitating her parents' financial decline. She marries four times and is complicit in the suicide of her second husband, Ralph Marvell. In short, Undine is a monstrous character. Critical reception of the novel considered her as such upon the novel's release in 1913. The New York Sun called her "sexless" and "repulsive," the "ideal monster in that at no time does she betray any human feelings" and The Nation was pithier in its review of Undine as "a mere monster of vulgarity" (Tuttleton, et al. 202-4). But the critics who read Undine as a consequence of the willful autonomy of the New Woman are missing the larger critique aimed at the leisure class to which Undine belongs and the encroachment of market ideas and values within the confines of the home. In his turn-of-the-century study on social classes in the United States, Thorstein Veblen's The Theory of the Leisure Class (1994) posits that the leisure-class wife's fundamental duty was to display her husband's wealth. Beyond positing the wife as ornamental chattel, the trouble with this outsized emphasis on consumerism and capital lay in the emulative desires of other social classes.

Expanding job markets and technological advancements of the last quarter of the nineteenth century led to a burgeoning middle class on both sides of the Atlantic. Businesses and large manufacturers responded with advertisements in newspapers and magazines that were reaching a larger audience. "By placing products in settings 
evocative of leisure and privilege," Debra-Ann MacComb (768) explains, "advertisers addressed nonrational yearnings encouraging consumers to project themselves into the constructed frame and savor thereby a richer and fuller life." The monstrosity of Undine, on one metaphorical plane, rests in her representation as a composite of this consumerist ethos. In the novel, the character of Charles Bowen, a New York society insider who seems most attuned to the comedy of his peers, calls Undine a "monstrously perfect result of the system" (Wharton, Custom 147). Wharton suggests that Undine's tutelage begins at home. To understand the source of her "overflowing activity," the author tells us "the answer would have been obtained by observing her father's business life" (83). In fact, her father acts the United States-based proxy for her demands when she starts the divorce proceedings against her American husband Ralph (precipitating his suicide) from France before acquiring her European husband, Raymond de Chelles.

Undine's European adventure begins in earnest upon Ralph's death. And though her flight to Paris is meant to attract the attentions of wealthy socialite Peter Van Degen, she encounters, and eventually marries, the handsome Marquis Raymond de Chelles. The protagonist's leap from the New York machinery into Parisian nobility is in some measure meant to highlight two cultures at inverse poles-as the United States surges into the vanguard position of a new era of market societies. According to Wharton, France's resistance to subjecting its history, traditions, and familial bonds to the sterilizing precepts of a market economy makes it superior to the United States in maintaining a transmittable notion of cultural identity for future generations. Raymond proves to be a disappointment to Undine in his embodiment of a nobility that is overwhelmed by the rising tide of bourgeois capitalism. Undine's desire to appraise the fifteenth-century tapestries of Raymond's ancestral chateau crystallizes this tension. He accuses her of representing a new breed of external conquerors from "towns as flimsy as paper," where "the people are as proud of changing as we [the French] are of holding to what we have" (379). Elsewhere in the novel, however, the sustaining ties between the United States' "New-World" dynamism and France's resistance belie a neat (white) ethno-cultural disjuncture between the two national spaces. The elderly Marquise de Chelles, Raymond's father, initially opposes marriage based on the seeming incongruity between her status as a twice-divorced Baptist from the United States and the solemn moral and religious traditions of French nobility. After Ralph's death, however, Undine's newly acquired inheritance prods the family to discover "the moral and financial merits" necessary to justify the young couple's union (337). The subsequent marriage of Raymond's younger brother to a wealthy American heiress further solidifies this reciprocity as the prestige of noble European heritage is accorded in exchange for the regenerative capital of the American nouveau-riche. This trans-Atlantic exchange improves the market value of the Chelles' property in Paris by, among other things, outfitting it 
with "electric light and heating" (350).

France's and the United States' ethno-cultural sensibilities are as deeply imbricated as to evoke the trans-Atlantic and trans-Pacific ontology of modern capitalist economies. These are not autonomously bound to the historical material conditions within national borders but are rooted in a logic of white European hegemony that orders racial, gender, and sexual dynamics on a global scale. The presence of black bodies, and with them the history of slavery and black subjugation, is almost entirely absent from Wharton's novel. However, this hidden history seeps symbolically from the damp walls and musty curtains of the Chelles' feudal real-estate wealth. The tapestries Undine wants sold (and eventually acquires herself) were gifted to Raymond's great-great grandfather by King Louis XV, whose revision of France's Code Noir helped bring wealth to the French empire by solidifying a legal framework for slavery and stabilizing the infrastructure of the sugarcane plantation economy in the Caribbean colonies.

\section{Helga Crane and the plight of the jungle}

If, for Wharton, the focus is the white, middle-class woman, Nella Larsen queries the existential conundrum of her black counterpart when the very fabric of the black family is already worn threadbare by the legacies of slavery and sexual exploitation. In examining the impact of the separate spheres for men and women, Amy Kaplan (582) re-evaluates the domestic sphere as indispensable to "imagining the nation as home." Such a reconceptualizing thus collapses the separate spheres and "[white] men and women become national allies against the alien, and the determining vision is not gender but racial demarcations and otherness" (582; emphasis added). In The Feeling of Kinship, David Eng applies a global capitalist lens to the notion of separate spheres when accounting for the spatial dislocation of "dark bodies" from the concept of the home as metaphor for nation. On a transnational scale, the racialized economies of slavery and colonialism affected the "material consolidation of the [white] bourgeoisie as a distinct class" separate from the formerly enslaved workers who furnished their material comforts (Eng 12). The alienation of the black body has both national and transnational dimensions in Larsen's works. In traversing the rural south, the urban north and the European metropole, she, far more explicitly than Wharton, shows how the black-diasporic body is barred from any notion of feeling at home in what are putatively liberal humanist societies. It is important to recognize that gender is inextricably linked to race in Larsen's demarcation of otherness. The black woman confronts a specific brand of racism that, in erasing her humanity, transforms her into a different type of monster-a purely sexual one.

Anne Stavney (535) explains that, during the first decades of the twentieth century, "assertions of black female immorality, impurity and licentiousness constituted a repeated refrain in white discussions of black America." In response to this pervasive 
belief, black writers strove to reconstruct the image of the black woman, placing her as someone comfortable in the trappings of a middle-class home and firm in her moral rectitude. In Reconstructing Womanhood (1987), Hazel Carby observes that Jesse Fauset, a prominent Harlem Renaissance writer, used her voice as a platform for fashioning a black middle-class morality that renounced the degeneracy associated with ideas of "the folk" and lionized the heteropatriarchal values of bourgeoisie. She asserts that Fauset's The Chinaberry Tree (1931) moves "away from the figures of isolated unmarried mothers and daughters supporting themselves" and towards a "newly formed and respectable community as dependent wives" (Carby 167). It is precisely against this ethic that Larsen wrote Quicksand, illustrating that marriage and childbirth are not a panacea for the black woman, when existing social and economic conditions merely perpetuate her problems.

Quicksand's protagonist Helga Crane's implacable restlessness sees her moving from the American South to Harlem, then to Copenhagen, before returning to the United States. It is a restlessness motored by alienation as a result of various strands of racism, classism, and sexism in the European and American socio-political body. Though Helga rails against the hypocrisy of the black middle class in Naxos and Harlem, her education and social mobility place her within this bourgeois milieu. Much like Undine, she is not averse to the consumerist ethos of a liberal capitalist society. Helga, we are told, always "had wanted, not money, but the things which money could give, leisure, attention, beautiful surroundings. Things. Things. Things" (Larsen 69). Abandoned by her black father and unwelcomed by her white family after her mother dies, the protagonist does not have the familial network and legacies that subtend the white middle class. Helga works for money. Her bouts with poverty give her a clear-eyed perspective on the power structures that dehumanize the majority working class. For instance, Helga transforms a school in Naxos into a machine that molds black students into commodities for the labor market, "It was, Helga decided, now only a big knife with cruelly sharp edges ruthlessly cutting all to a pattern, the white man's pattern" (8).

According to Nikhil Pal Singh's Black Is A Country, a growing number of Marxist black activists in the first half of the twentieth century believed that eliminating class differentiation would solve the social problems of the black community. For Larsen, race critically intersects with class in the language of worker exploitation in fomenting entirely different concerns for black workers. Helga is denied access to jobs for which her education otherwise qualifies her. For Larsen's protagonist, the specter of her sexuality cannot be disarticulated from her construct as a labor commodity. While interviewing for jobs in Chicago, she encounters a "few men, both white and black, [that] offer her money, but the price of the money [is] too dear," and Helga does "not feel inclined to pay it" (Larsen 37). It is this anxiety around the formulations of her sexuality that intersect with the protagonist's sense of racial identification. Though 
Helga attempts to escape whiteness while in Harlem, she cannot escape its formulations of her as a sexually libidinous Other. Though keenly aware of the absurdities of the black bourgeoisie, as encapsulated by the character of Anne Grey (who apes white people's customs while sternly decrying all things white), she also cannot embrace the sexual autonomy of a figure like Audrey Denney, the self-assured black woman who sits at ease in a nightclub and slips freely across the line separating Harlem and white New York. Larsen dramatizes Helga's turmoil by exposing her psychological intercourse with the heady jazz music wafting through that nightclub:

She is drugged, lifted, sustained by the extraordinary music, blown out, ripped out, beaten out, by the wild, murky orchestra. The essence of life seems bodily motion. And when suddenly the music dies, she drags herself back to the present with a conscious effort and a shameful certainty that not only has she been in the jungle, but that she has enjoyed it. (61)

Helga's pre-conscience, Larsen suggests, is tied to essentialized notions of blackness-creativity, bodily abandon, and sexual expressiveness. It is significant that, during her moment of reclaiming reason, she shunts this feeling into the realm of "the jungle," appropriating (and endorsing) colonialist and white supremacist rhetoric that removes blackness from the spheres of rationality and domesticity. It is significant too that, for Helga, this place of essentialized blackness is invariably tied to the erotic. The shame she experiences here is the same that attends her sexual longing for Robert Anderson, the principal from the school in Naxos who struggles with his desire for Helga. Though previously engaged to a man who did not excite her sexually, her desire for Robert ignites in her a "primitive emotion" that leaves her "panting," "confused," and longing for escape (64).

Her inheritance from her white uncle gives her the financial resources to flee the United States but her experiences in Europe make clear that the liberal humanism that marks her as Other spans a trans-Atlantic reach deeply rooted in colonialism. The twice-divorced Undine can marry into French aristocracy, despite significant differences in religious and sexual attitudes, because her whiteness ties her to capitalist production. The jewel-encrusted hairpins and brilliant dresses add to Undine's appeal as a consumable object with a beauty "brushed by the wing of poetry" (Wharton, Custom 194). On the other hand, Helga's batik dresses, enameled earrings, and Manila shawls expose her as "a veritable savage" amidst the Copenhageners "who stop to stare at the queer dark creature, strange to their city" (Larsen 71). This dichotomy affirms Sandra Gilman's observation on late nineteenth-century perceptions around racialized sexuality in the arts and sciences. Whereas the body of white women could contain multiple meanings, the black woman "comes to serve as an icon for black sexuality in general" (Gilman 212).

When Helga firsts arrives to Europe, it is the visual and cultural antithesis of the 
racialized landscapes that she has known. She rarely thinks of the United States "excepting in unfavorable contrast to Denmark" (Larsen 76). The serene lakes, charming canals, and quaint "low-lying Exchange, a picturesque structure in picturesque surroundings" (78), project a European culture scrubbed clean of the inimical differentiation that animates the terms of squalor and poverty for black citizens at home. Helga certainly feels differentiated upon arriving in Copenhagen, but her cautious befuddlement at the Danes' predisposition to emphasize (rather than pretending to ignore) her differences gives way to a full-throated endorsement that abets her sense of being born anew in the midst of their homogeneity. The Danes, she believes have "the right idea [...] Enhance what was already in one's possession. In America, Negroes sometimes talked loudly of this, but in their hearts they repudiated it" (76). This affect of renewal conjures the desires of famous black American expatriates to Europe, among them Josephine Baker, Ada "Bricktop" Smith, and Richard Wright. In speaking to these transnational longings, Paul Gilroy (19) points out that for people such as Wright, Europe offered the possibility of transcending "the restrictive bonds of ethnicity, national identification and sometimes even 'race' itself" that could prove overwhelming in the race-consciousness of the Anglophone Americas.

Still, the differentiation Helga finds refreshing at the outset of her European journey is ultimately tied to similar patterns of marginalization. The Danish women's indifference to Helga's 'alluring' exoticism when she is first introduced at an evening party thrown by her Aunt Katrina do not stem from enlightened politeness, but a deep-seated racism that marks Helga as inferior. As Larsen's protagonist surmises, "she was attractive, unusual in an exotic, almost savage way, but she wasn't one of them. She didn't at all count" (Larsen 72). Helga's initial portrait of a European utopia antithetical to the disharmony of a racially heterogenous society may very well, as Arne Lunde and Anna Westerstal Stenport (231) charge, contradict not only the historical presence of Afro-Caribbeans in early twentieth-century Copenhagen but also "Denmark's history as a colonial power and involvement in the trans-Atlantic slave trade." However, the abjection Helga inevitably comes to feel ultimately alters how the reader initially imagines the space. This affective recalibration evokes, for instance, the history of slave trading in Danish wealth and its embodiment in the picturesque structure of the "low-lying Exchange" (Larsen 78), the Stock Exchange built in 1640 that now serves as the headquarters of the Danish Chamber of Commerce in the novel.

Racial differentiation has its most dramatic impact during Helga's visit to a vaudeville act towards the end of her European journey. Her longing to return to black Harlem is made more acute by her Danish acquaintances' orgiastic response to the black men performing minstrelsy. Their howling and screaming and clapping in response to the exaggerated twisting and cavorting of black limbs makes Helga feel exposed, ashamed, and certain that "all along they had divined [that] presence, had 
known that in her was something, some characteristic, different from any that they themselves possessed" (85). And though Helga vows to embrace this difference, it also cements her status as one of immanent exile. The terms of European enlightenment, whose history is intimately tied to the functions of colonialism and that survives as the central ordering logic for Global North nations, locates the concept of blackness as an inferior Other. While for Fru Fischer, this logically renders jazz as inferior to the music of Gade and Heise (82) and registers black female bodies as the antithetical excess in relation to white European womanhood.

Similarly, Danish artist Alex Olsen's initial appraisal of Helga is purely sexual and symbolically recalls the very physical terms on which enslaved Africans were filtered into the logic of colonialism. Aunt Katrina introduces the famous artist to Helga in hopes that a connection between the two would elevate her social standing but Olsen's interest in her rests plainly in her potential as a commodity. He never addresses her, rendering her mute, and her initially frail grasp of Danish reduces his appraisal of her to an amalgam of body parts: "Superb eyes ... color ... neck column ... yellow ... hair ... alive ... wonderful" (73). Despite its positive register, it conjures the physical plane along which black bodies were welcome in the logic of colonial Europe. The portrait of her by Olsen is an aesthetic reflection of this commoditization of the black female body as a sexual object. What the artist perceives and distils as "the true Helga Crane," Helga herself sees "some disgusting sensual creature with her features" (91). The fractured psyche of the black citizen, Larsen suggests, is inevitable when her racial self is mediated through constructions of her identity by a cultural majority that stakes its normative claim on the production of alterities. Or, as Anne Hostetler (36) claims, while Helga is annoyed by such representations as Olsen's, "she cannot entirely dismiss them, for she half believes them." Speaking to the fractured psychic conditions of African Americans following the First World War, Paula Giddings (183) comments that "blacks found postwar America a hall of mirrors, where they saw their reflection first from one angle, then from another." It is out of this place of trauma and unbelonging that Larsen's protagonist voices her ultimate rebellion by refusing to participate in the contract of reproduction and futurity. Helga's question upon her return to Harlem-“Why do Negroes have children?" (Larsen 96) - is not naïve posturing, but a damning remark on the doomed futurity of the black-citizen body menaced by a differentiation and alienation that is fundamentally racial, and which cannot be resolved by efforts at economic parity.

\section{Conclusion}

Edith Wharton's The Custom of the Country and Nella Larsen's Quicksand share much in common in terms of their preoccupation with the condition of women amidst the fervent social and economic changes taking place in the late nineteenth- and early twentieth-centuries. While the resources specific to Undine (Custom) and Helga 
(Quicksand) allowed each a measure of freedom and trans-Atlantic mobility not common to vast working-class populations of women in North America and Western Europe at the time, they also each served as exemplars of the structural limitations that marriage imposed on women. Wharton's concerns are, however, limited to a society of wealthy white elites that evidence, as Ammons (74) points out, her alignment of "the West" with whiteness. Helga's story thus challenges Wharton's limited outlook. Race and class, alongside gender, emerge as crucial lenses in Larsen's dialectic to assess the conditions of women. Helga, unlike Undine, must contend with the notion of being an Other within the scope of a dominant white ideology that determines the terms of cultural and capital output in both Europe and America. Larsen's abortive attempt at forging affective ties, both intimate and familial, in Denmark shows how the possibility of unambiguous assimilation into the productive avenues of Western capitalist societies are foreclosed to black women, as their structures were built and continue to thrive on the expropriation of black bodies for labor and wealth creation (and not acquisition).

\section{Acknowledgements}

I would like to thank Dr. Stephanie Smith for providing the intellectual insights that led to the idea for this paper. I would also like to thank Dr. Mandisa Haarhoff for her encouragement in getting the paper ready for publication.

\section{Works Cited}

Alexander, Jacqui M. "Not Just (Any) Body Can Be a Citizen: The Politics of Law, Sexuality and Postcoloniality in Trinidad and Tobago and the Bahamas." Feminist Review vol. 48, 1994, pp. 5-23. DOI: https:// doi.org/10.2307/1395166.

Ammons, Elizabeth. "Edith Wharton and the Issue of Race." The Cambridge Companion to Edith Wharton. Ed. Millicent Bell. Cambridge U P, 1995, pp. 68-86.

Carby, Hazel. Reconstructing Womanhood: The Emergence of the Afro-American Woman Novelist. Oxford U P, 1987.

Cott, Nancy F. The Bonds of Womanhood: "Woman's Sphere" in New England, 1780-1835. Yale U P, 1997.

Cunningham, Gail. The New Woman and the Victorian Novel. Macmillan, 1978.

Bromell, Nick. "Reading Democratically: Pedagogies of Difference and Practices of Listening in The House of Mirth and Passing." American Literature vol. 81, no. 2, 2009, pp. 281-303. DOI: https://doi. org/10.1215/00029831-2009-003.

Dittmar, Linda. "When Privilege Is No Protection: The Woman Artist in Quicksand and The House of Mirth." Writing the Woman Artist: Essays on Poetics, Politics and Portraiture. Ed. Suzanne W. Jones. U of Pennsylvania P, 1991, pp. 133-54.

Eng, David. The Feeling of Kinship: Queer Liberalism and the Racialization of Intimacy. Duke U P, 2010.

Giddings, Paula. When and Where I Enter: The Impact of Black Women on Race and Sex in America. Morrow, 1984.

Gilman, Sandra. "Black Bodies, White Bodies: Toward an Iconography of Female Sexuality in Late Nineteenth-Century Art, Medicine and Literature." Critical Inquiry vol. 12, no. 1, 1985, pp. $204-42$. DOI: https://doi.org/10.1086/448327.

Gilroy, Paul. The Black Atlantic: Modernity and Double Consciousness. Harvard U P, 1993.

Hoeller, Hildegard. "Invisible Blackness in Edith Wharton's Old New York." African American Review vol. 44, no. 1-2, 2011, pp. 49-66. muse.jhu.edu/article/469695. Accessed 19 Feb. 2019.

Hostetler, Anne E. “The Aesthetics of Race and Gender in Nella Larsen's Quicksand.” PMLA vol. 105, no. 1, 1990, pp. 35-46. DOI: https://doi.org/10.2307/462341. 
Hutchinson, Stuart. "Sex, Race and Class in Edith Wharton." Texas Studies in Literature and Language vol. 42, no. 4, 2000, pp. 431-44. https://www.jstor.org/stable/40755319. Accessed 19 Feb. 2019.

Kaplan, Amy. "Manifest Domesticity." American Literature vol. 70, no. 3, 1998, pp. 581-606. DOI: https:// doi.org/10.2307/2902710.

Kowaleski-Wallace, Beth. "The Reader as Misogynist in The Custom of the Country." Modern Language Studies vol. 21, no. 1, 1991, pp. 45-53. DOI: https://doi.org/10.2307/3195117.

Larsen, Nella. Quicksand. Penguin, 2002.

MacComb, Debra Ann. "New Wives for Old: Divorce and the Leisure-Class Market in Edith Wharton's The Custom of the Country." American Literature vol. 68, no. 4, 1996, pp. 765-97. DOI: https://doi. org $/ 10.2307 / 2928137$.

Orlando, Emily. "Irreverent Intimacy: Nella Larsen's Revisions of Edith Wharton." Twentieth Century Literature vol. 61, no. 1, 2015, pp. 32-62. DOI: https://doi.org/10.1215/0041462X-2885176.

Singh, Nikhil P. Black Is A Country: Race and the Unfinished Struggle for Democracy. Harvard U P, 2005.

Stavney, Anne. "'Mothers of Tomorrow:' The New Negro Renaissance and the Politics of Maternal Representation." African American Review vol. 32, no. 4, 1998, pp. 533-61. DOI: https://doi.org/10.2307/2901236.

Tocqueville, Alexis \& Thomas Bender. Democracy in America. Modern Library, 1981.

Tuttleton, James, et al. Edith Wharton: The Contemporary Reviews. Cambridge U P, 2010.

Veblen, Thorstein. The Theory of the Leisure Class. Dover, 1994.

Wharton, Edith. The Custom of the Country. Random House, 1994. . Twilight Sleep. Scribner's, 1997.

Young, Elizabeth. Black Frankenstein: The Making of an American Monster. NYU P, 2008. 